\title{
Improve Implementing Mega Building Envelope upon arriving material using lean six sigma: case study
}

\author{
Enass Salama ${ }^{1}$, Nesreen Khalil. ${ }^{2}$
}

\begin{abstract}
A b s t r act
The functional performance of a building envelope depends on the correct specifications of the individual components that make up the envelope mounting system, the quality of manufacture of these components, and thus the installation standard. Good performance also requires a high degree of interaction between building envelope installations.
\end{abstract}

This interaction requires identifying activities that complement each other, and thus the strength and willingness of those wanted to request a "whole building envelope". Therefore, well-installed envelope can ensure that occupants have productive and healthy indoor environments.

This paper proposed a methodology by integration three different framework (Lean, Six-Sigma and mega building envelope installation) during a systematic approach to improve building envelope installation and eliminate redundant time and materials, upon arriving material to the site.

Our aim was to demonstrate through a project in hotel towers in Egypt in Cairo - Maadi (upon the arrival of mega enveloping materials for construction) that the methodology has the potential to reduce material waste, time duration, and potential savings while integrating (Lean, Six Sigma framework using their tools) In the framework of implementing the mega building envelope upon arrival of materials \} inspired by the work and practices of various building envelopes companies.

Keywords: Mega building envelope - implementation - upon arrive material Process - Lean- Six Sigma - waste.

\section{Introduction}

Envelopes are the first aesthetic feature of buildings that distinguish one building from another and therefore the most important characteristic that quantifies \& qualifies the performance of the building. These envelopes are different within the

\footnotetext{
${ }^{1}$ Teacher assistant at Modern Academy for Engineering and Technology (Maadi)

${ }^{2}$ Associate. Professor, Architectural Dept, faculty of Engineering Matariya, Helwan University
} 
reinstallation methods in the mega buildings which they defined them in several ways as followed:

- It's a long span buildings that create unobstructed, column-free spaces greater than $30 \mathrm{~m}$ (100 feet) for a variety of functions / activities (1) ex : auditoriums, covered stadiums, exhibition halls and aircraft hangars.

- It is a tall building (high rise) and is defined differently in terms of height depending on the jurisdiction. It's used as residential buildings, offices, or other functions including hotel, retail, or with multiple purposes combined (2).There is no clear difference between a tower block and a skyscraper, although a building with forty or more stories and taller than $150 \mathrm{~m}$ (490 ft) is generally considered during a vertical building .

There are several processes of implementing mega building envelopes upon arriving materials to the site which has been explained by different envelope companies in a several ways and priorities.(3)

So to avoid defects in implementing mega building envelopes upon arriving materials researcher collected this information about these operations from various companies and identified the most important activities as follows:

- Preparation: It is the first stage to making sure of safe, efficient, and troublefree installation should be taken well before any installation operatives reach site.

- Receive and transport materials from trucks

The envelope materials are typically delivered on trailer units and access will be required for the vehicle to maneuver around all sides of the building.

- Handling and storage: When the materials reach site.

These activities include several sub activities the researcher will explain them in (table 1- 2) as a part of the framework of (implementing mega building envelopes upon arriving materials).

The problem during this paper is "There are some defects which led to not get the optimum efficiency and effectiveness of implementing mega building envelopes upon arriving material to the site which led to process several wastes within the project (time, cost, material...) which face several envelope companies.

Time and material analysis, were convinced the envelope project manager and therefore the project manager because the project took too long time to implement and a desire to expedite its completion and delivery, especially from the envelope project manager. 


\section{Lean, Six Sigma}

Lean and Six Sigma are two different frameworks acknowledged business process improvement strategies available to organizations today for achieving dramatic results in cost, quality and time by focusing on process performance. "Sigma" is used as a metric that reflects a company's ability to manufacture a product or provide a service within specified specification limits (or without defects). (4)

Six Sigma continuous improvement framework known as DMAIC (Define, Measure, Analyze, Improve and Control) aims to (enhance the efficiency of existing processes and increase customer satisfaction through envelope installation and services).

DMAIC framework is the integration of several tools such as QFD (Quality Function Deployment), SPC (Statistical Quality Control), and FMEA (Failure Mode and Effects Analysis) in a logical direction. This approach will be explained in a case study. (5)

Lean Construction is an efficient technology aimed at eliminating waste in construction. The goal of Lean Construction is to achieve customer satisfaction by using less of everything for example: materials, money and resources. This construction method is best suited for complex and speed projects. It develops teamwork and also assigns matching labor to proper work. (6)
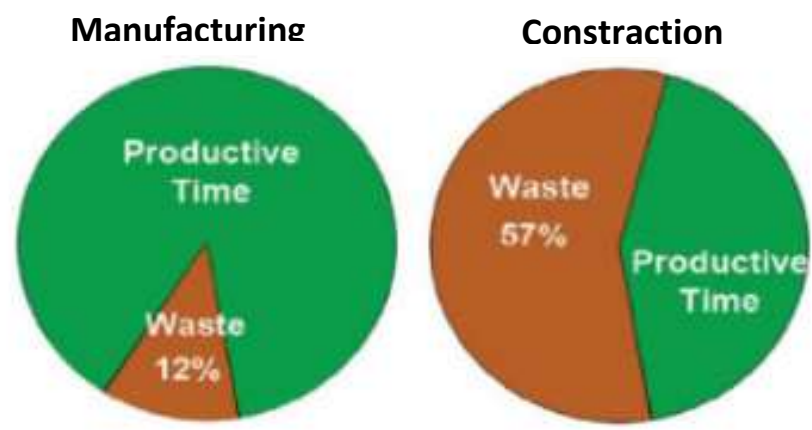

Figure 1: Waste percentages of time in manufacturing and construction

Source: R. F. Aziz, S. M. Hafez, Applying lean thinking in construction and performance improvement, Alexandria Engineering Journal Vol. 52, Issue 4, Alexandria University, 2013, pp.

There are several tools and Lean techniques that can be used to improve performance in the construction industry and to ensure efficient processes in the pre-construction, construction and maintenance stages of the project such as: (7) Flow process (8), Pull approach (9), Continuous improvement and transparency. (10)

During the 2000s, Lean Six Sigma methodology took off from Six Sigma and became its unique process. The first concept for Lean Six Sigma was created in 2001, by a book titled Leaning into Six Sigma: The Path to Integration of Lean Enterprise, and Six Sigma by (Barbara Witt, Chuck Mills, and Mike Carnell). (11) 
Lean and Six Sigma (Efficiency and Effectiveness) is a business strategy that provides a methodology that increases process performance results, increases customer satisfaction and helps make the process more cost-effective. It is a good tool for leadership and employee development.

Lean principles focus mostly on the speed of the process. With the help of statistical controls Six Sigma leads to quality improvement. It is recommended to use the Lean principles and Six Sigma framework side by side. The traditional Six Sigma focuses on improving the quality of process results (effectiveness) while Lean management focuses on speed and minimizing waste. (12)

The comprehensive set of tools, techniques, and principles that can be used in the integrated approach to Lean and Six Sigma business strategies are outlined in Figure2 which based on previous work of experts in Lean and Six Sigma. (13)

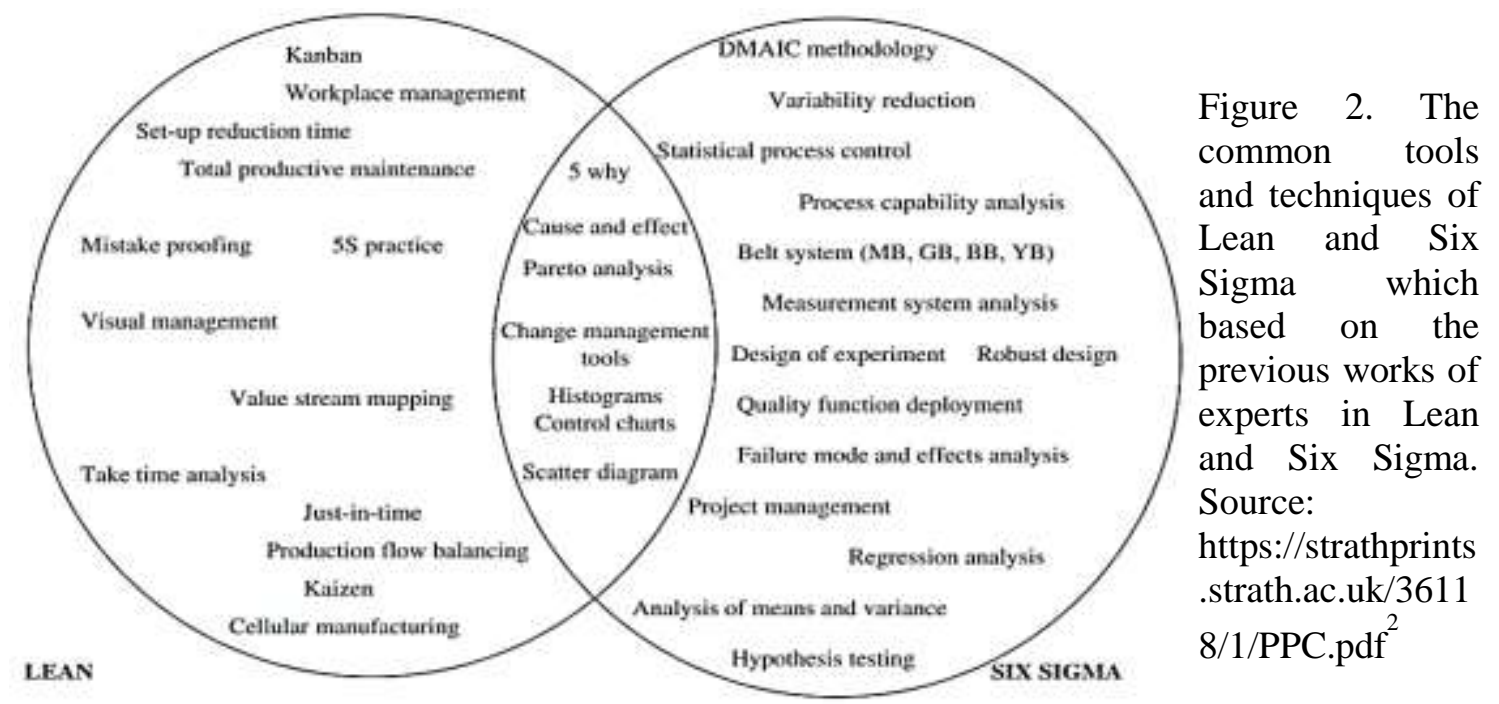

\section{Methodology}

This work develops a methodology while integrating three different frameworks - Lean, Six-Sigma, and the implementation of Mega building envelope upon materials arrive - into a systematic approach with the goal of improving the quality and output impact of time and materials in the construction process..

By surveying and studying the process of various companies in implementing mega building envelope upon arriving material, the researcher will have a framework for

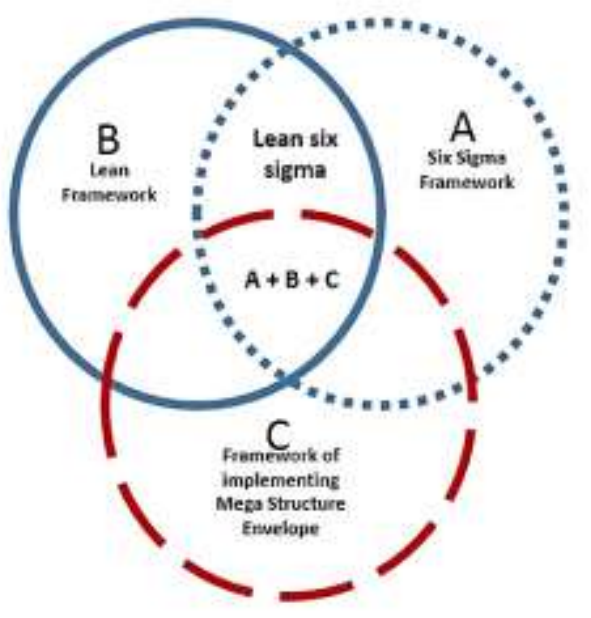

Figure 3: methodology with integrating three frameworks (Lean, Six-Sigma and implementing mega building envelope upon arriving materials) 
implementing mega building envelope upon arriving materials.

The methodology will be based on the Six-sigma DMAIC framework with its specific tools, Lean tools, and Mega building envelope installation framework upon arriving material dependent on their process shown below in Table1, 2.

A case study will be conducted to clarify the application of the methodology and

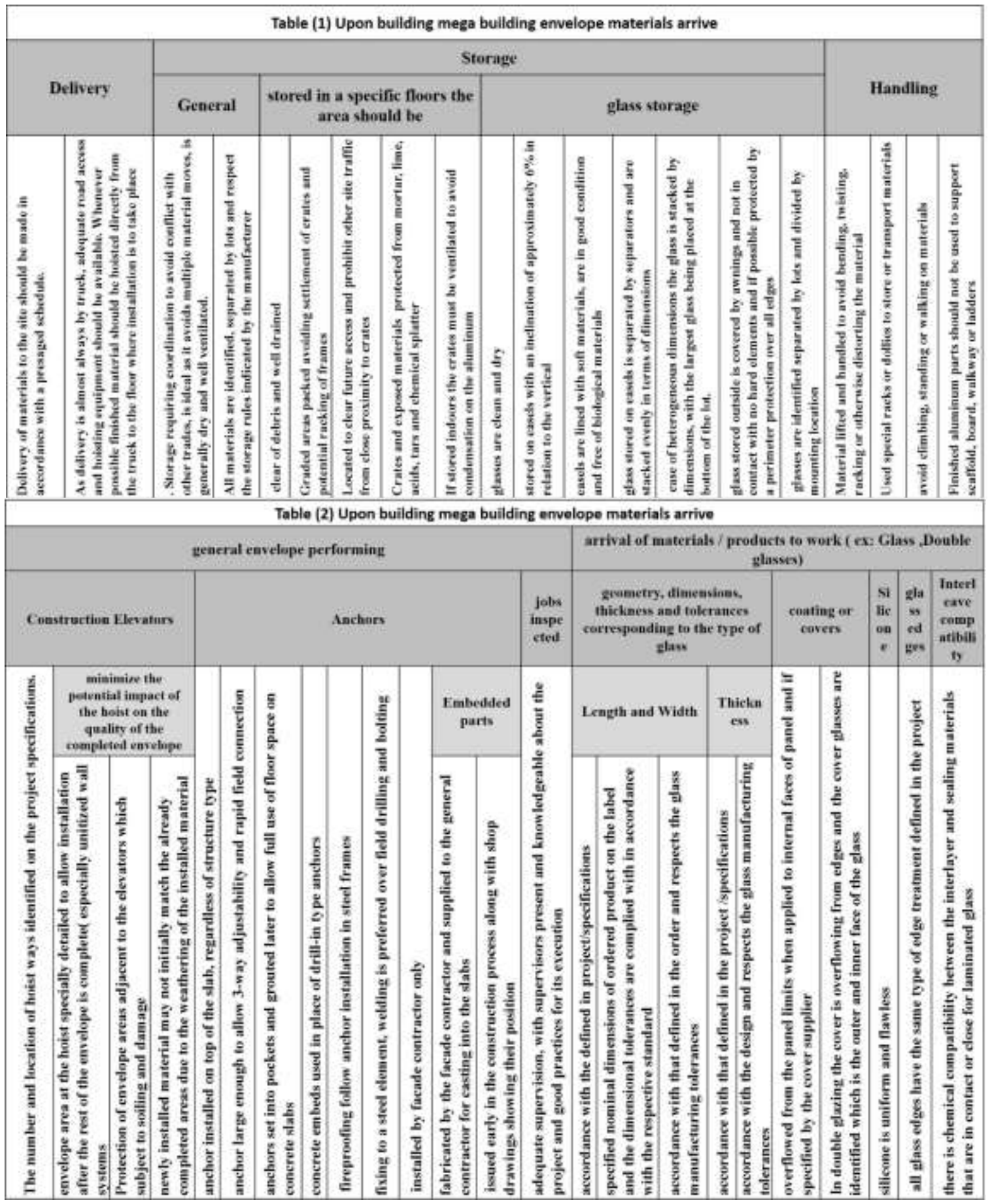


the associated results. The study highlights the implementation of the mega building envelope (upon building envelope materials reach the site).

\section{Case study:}

A case study was presented through the literature and some interviews were conducted with the project manager, envelope project manager, and site workers to assist the researcher in obtaining a methodology by integrating Lean, Six Sigma, and Mega building envelope implementation frameworks (upon arrival materials) together to improve process performance and reduce material waste and time duration of implementing mega building envelope uppon arriving material.

Construction started in 2016, the planned completion date is in 2020, the project is a mega building consisting of two towers connected by a large glass link that contains several functions such as reception, administration,....) in the name of Secon Nile Towers. The towers will be a hotel and hotel apartment function, owned by Saudi Egyptian Developers and the envelope installation company is Alunile.

The project has a very interesting shape referring to the high-rise buildings that have 23 floors above ground and 2 floors underground over an area of more than 10,000 square meters and the height of these towers is about $72 \mathrm{~m}$. As shown in Figure1.

The methodology was presented and explained to the contractor, project manager and envelope engineer during the on-site inspection and data collection stages that took over two months (May, June 2020). On-site investigation has been completed for all study units to identify major issues of project delay by envelope project manager, project manager and their objections.

The methodology was then applied to a part of the building envelope (the skylight for the connection between the two towers) (200m 2 and $18 \mathrm{~m} 2$ height) to help analyze the root causes of increasing project duration and delaying of this building envelope part (upon arriving there material). This is done in 3 processes to supply the material (glass) needed for this part to the site as follows:

1- Dropping off materials from trucks and visual inspection. 2- Transferring the materials to the specified storage area. 3- Storage and inspection. This 3 process will be the same on 3 shipments on different days.

\section{Resultes and discussion}

To demonstrate the implementation of the methodology first, we defined activities (major - sub) for this case study of implementaing mega building envelope (upon arriving materials) as shown in Table 1, 2 . 
Secound the methodology will base on Six-sigma's DMAIC with their identification tools and Lean tools. We will review each stage in the process as each plays an important part in obtaining results as follows::

\section{- Stage 1: Define}

Participating parties: Envelope project manager (Alunlie Company), project manager and the project general contractor.

Activities: 1- Define the process and activities of this stage. 2- Determine the customer's request and take care of it. 3- Identifying the problems that cause low customer satisfaction..

Tools: Brainstorm, Follow chart and Voice of Customer (VOC) tools (14).

To collect the Voice of Customer, interviews will be conducted with the envelope project manager (project champion), the project manager (customer) and the general contractor for the project, and these voices will be translated into Critical Client Requirements (CCR) as shown in Table 3.

$\mathrm{CCR}$ is a translation data from the $\mathrm{VoC}$ into quantitative data and has many advantages such as identifying, measuring, and describing what the customer wants and how to achieve it..

Table 3 : Translation of Voice of Customer of mega envelope installation into Critical Requirements

\begin{tabular}{|c|c|c|c|c|}
\hline No & Voice of Customer & $\begin{array}{l}\text { Process } \\
\text { Custom } \\
\text { er }\end{array}$ & $\begin{array}{l}\text { Clarification } \\
\text { The process }\end{array}$ & $\begin{array}{c}\text { Customer Critical } \\
\text { Requirement }\end{array}$ \\
\hline 1 & $\begin{array}{l}\text { Hoisting equipment are } \\
\text { often not existed and } \\
\text { ready while material } \\
\text { delivered by trucks to the } \\
\text { project to store them. }\end{array}$ & $\begin{array}{l}\text { Envelope } \\
\text { project } \\
\text { manager } \\
\text { (Alunile) }\end{array}$ & $\begin{array}{l}\text { - Based on using them } \\
\text { by other works in the site } \\
\text { - Bad coordination }\end{array}$ & $\begin{array}{l}\text { Provide the need of cranes } \\
\text { during the arrival of materials } \\
\text { to store them in floors }\end{array}$ \\
\hline 2 & $\begin{array}{l}\text { Sometimes worker not } \\
\text { respect the storage rules } \\
\text { indicated by the } \\
\text { manufacturer }\end{array}$ & $\begin{array}{l}\text { General } \\
\text { project } \\
\text { manager }\end{array}$ & $\begin{array}{l}\text {-Mess envelope } \\
\text { supervision from alunile } \\
\text { company } \\
\text { - Lack of workers } \\
\text { awareness }\end{array}$ & $\begin{array}{l}\text {-Have more worker } \\
\text { awareness } \\
\text { - Increased the attention and } \\
\text { supervision from the } \\
\text { envelope manager }\end{array}$ \\
\hline 3 & $\begin{array}{l}\text { Much of worker to } \\
\text { transfer the material to } \\
\text { the storage space }\end{array}$ & $\begin{array}{l}\text {-Envelope } \\
\text { project } \\
\text { manager } \\
\text { (Alunile) }\end{array}$ & $\begin{array}{l}\text { - depend on the way of } \\
\text { transferring }\end{array}$ & $\begin{array}{l}\text {-Have glass vacuum for } \\
\text { transferring materials }\end{array}$ \\
\hline 4 & $\begin{array}{l}\text { Some aluminum stored } \\
\text { outside not in a good } \\
\text { way }\end{array}$ & $\begin{array}{l}\text {-Envelope } \\
\text { project } \\
\text { manager } \\
\text { (Alunile) }\end{array}$ & $\begin{array}{l}\text { - Not respect the storage } \\
\text { rules } \\
\text { - Mess coordination - } \\
\text { Lack of workers } \\
\text { awareness }\end{array}$ & $\begin{array}{l}\text {-Have more worker } \\
\text { awareness and Attention to } \\
\text { supervision }\end{array}$ \\
\hline 5 & $\begin{array}{l}\text { Some glass stored } \\
\text { outside is not covered by } \\
\text { awnings and in contact } \\
\text { with hard elements }\end{array}$ & $\begin{array}{l}\text {-Envelope } \\
\text { project } \\
\text { manager } \\
\text { (Alunile) }\end{array}$ & $\begin{array}{l}\text { - Mess coordinate } \\
\text { - Lack of workers } \\
\text { awareness }\end{array}$ & $\begin{array}{l}\text {-Have more worker } \\
\text { awareness and Attention to } \\
\text { supervision }\end{array}$ \\
\hline
\end{tabular}




\begin{tabular}{|c|l|l|l|l|}
\hline $\mathbf{6}$ & $\begin{array}{l}\text { Some envelope areas } \\
\text { adjacent to the elevators } \\
\text { not protected of which } \\
\text { subject to damage }\end{array}$ & $\begin{array}{l}\text {-Envelope } \\
\text { project } \\
\text { manager } \\
\text { (Alunile) }\end{array}$ & $\begin{array}{l}\text { Based on other works in } \\
\text { the site } \\
\text {-Mess coordination }\end{array}$ & $\begin{array}{l}\text { - Other works in the site must } \\
\text { consider envelope material } \\
\text { and not to destroy it. } \\
\text { More Attention to } \\
\text { supervision }\end{array}$ \\
\hline $\mathbf{7}$ & $\begin{array}{l}\text { Negligence of } \\
\text { supervisors sometimes } \\
\text { and their number is few }\end{array}$ & $\begin{array}{l}\text {-General } \\
\text { project } \\
\text { manager }\end{array}$ & $\begin{array}{l}\text { - Based on several } \\
\text { management supervise } \\
\text { the site which get } \\
\text { supervisors negligence }\end{array}$ & $\begin{array}{l}\text { - Focus on effective } \\
\text { supervision and management } \\
\text {-have more number of } \\
\text { supervision }\end{array}$ \\
\hline $\mathbf{8}$ & $\begin{array}{l}\text { Take a long time to } \\
\text { transfer and storage } \\
\text { materials }\end{array}$ & $\begin{array}{l}\text {-Envelope } \\
\text { project } \\
\text { manager } \\
\text { Alunile) }\end{array}$ & $\begin{array}{l}\text { - The way for transfer } \\
\text { - Awareness of worker } \\
\text { - Few number of checker }\end{array}$ & $\begin{array}{l}\text { - Recycled on site and wasted } \\
\text { from cladding sheets }\end{array}$ \\
\hline
\end{tabular}

Then using the Follow chart tool (Fig 4) will define the process of implementing mega building envelope upon arriving materials.

\section{- Stage 2: Measure}

Participating parties: Envelope project manager (Alunlie Company), project manager.

Activities: 1- Monitoring the process 2- Determining performance standards based on customer requirements 3- Focusing on outputs and have the standard system. Tools: IPO (Input Process Output) (15) and VSM (Value Stream Mapping) (16).

In the first step of this stage project team (researcher, envelope project manager, and project manager) developed an Input Process-Output (IPO) Diagram to measure the process to be improved, the variables that affected the results, and what output metric was measured as a result of this project. This IPO diagram is shown in Figure5.

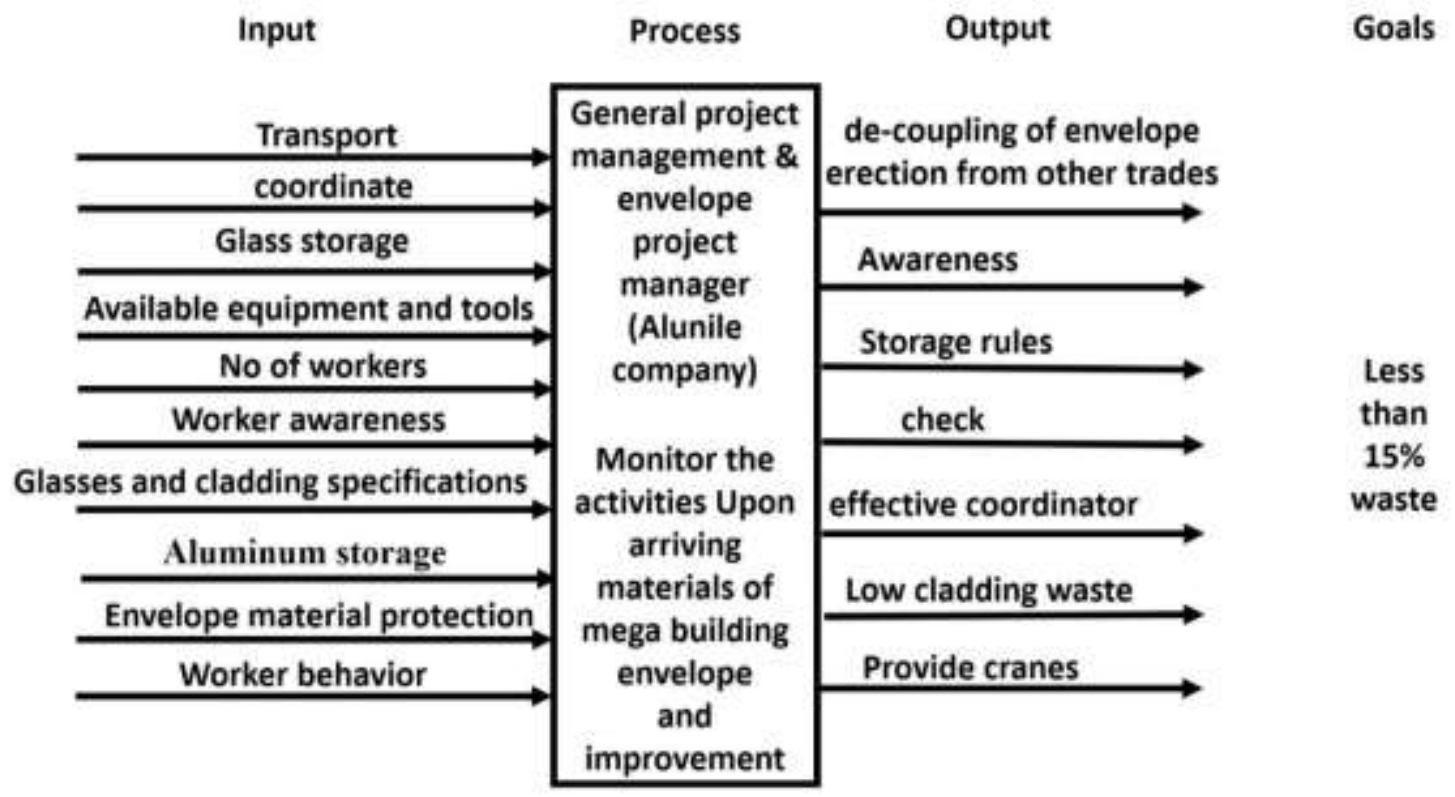

Figure 5: Input Process-Output (IPO) Diagram to measure what process to be improved 


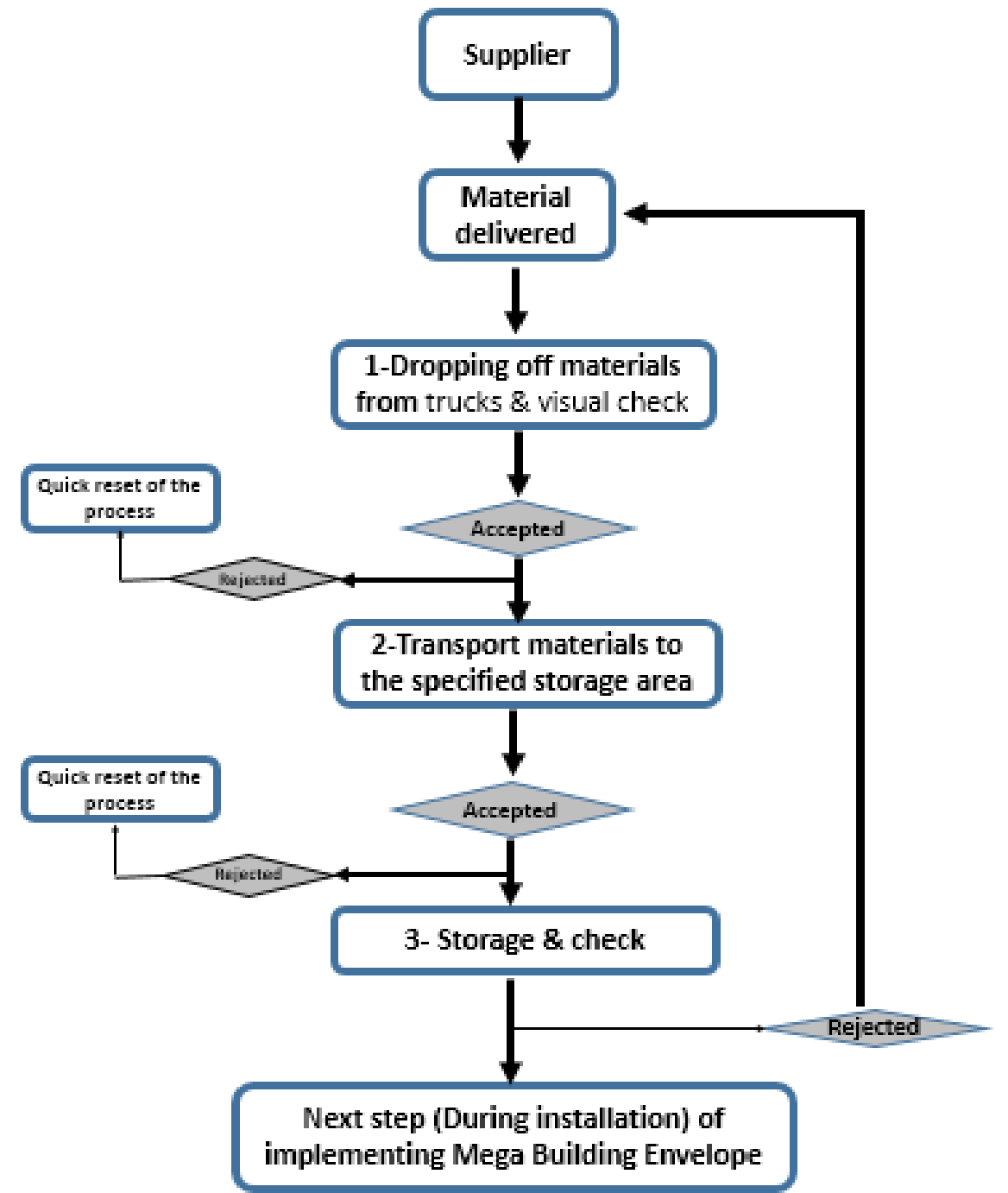

Figure 4: follow chart define the process of implementing mega building envelope upon arriving materials

It determined what should be measured which is based on VOC (Voice of the Customer). As shown in Figure 6 of the vsm map (Value Stream Diagram), expected output to be measured from this project which depend on the number of materials per supply (glasses), and the first supply was on (4/6/2020) as follows:

- Number of trucks transporting skylight glasses (3 trucks)

- Material quantity (35 pieces per supply)

- Glass size (6-8 m2)

- Number of workers (per supply)

- Duration of work (loading - transporting - storing - checking) (hours)

- Number of cranes for storing materials in floors

- Methods of transporting materials (for each supply) 


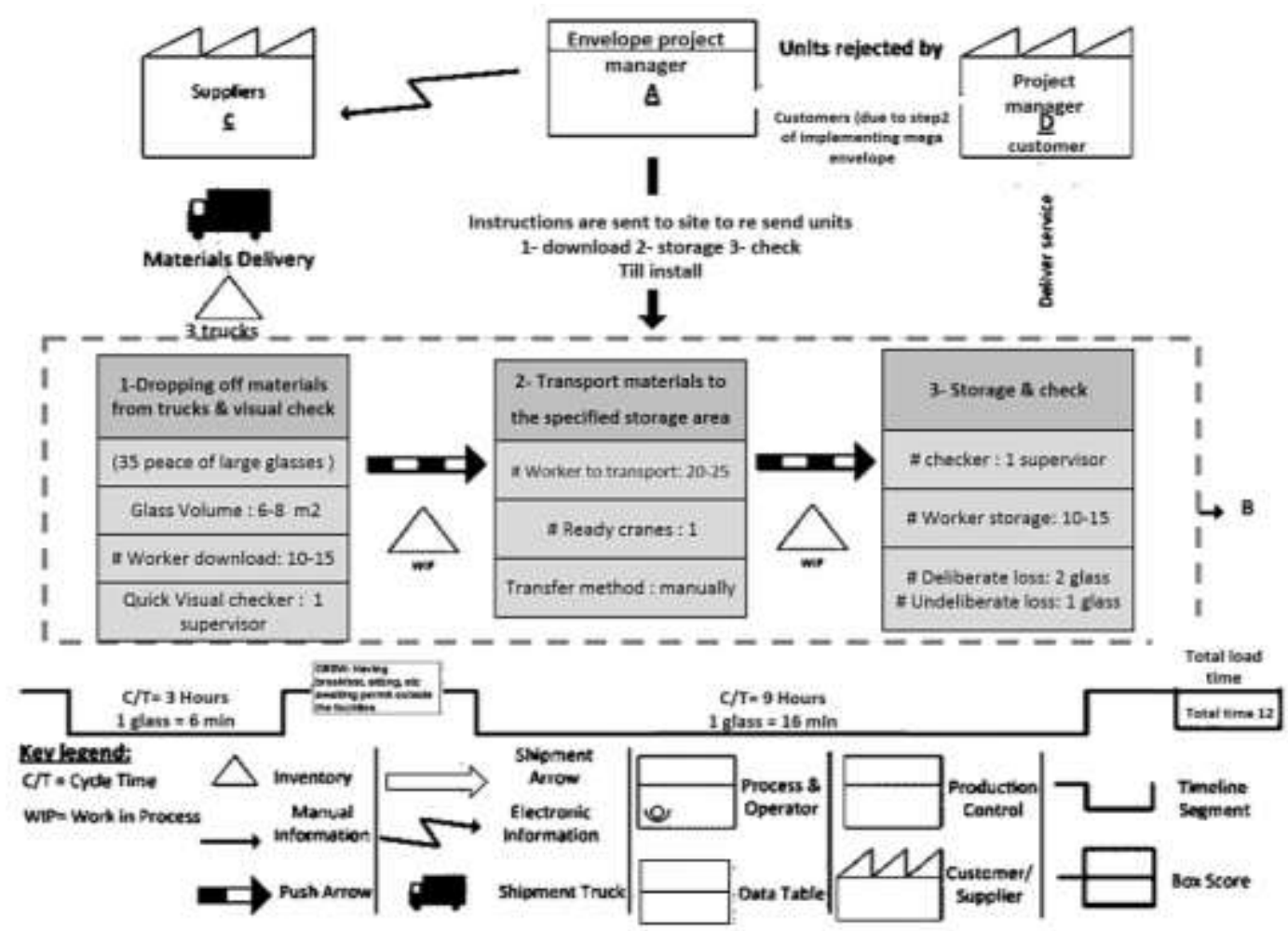

Figure 6. Value Stream Mapping of team work preparation process. Source: researcher (Before improvement)

1- Dropping off from trucks \& visual inspection: This process provides between 10 to 15 workers to unload 35 large pieces of glass (size $=6-8 \mathrm{~m} 2$ ) (It's a large number of worker). While the materials were downloaded, there was one fast visual supervisor for the process which allowed the workers not to commit to the proper download of the expensive items and thus wasted materials and hence time and money. Figure 17.

2- Transferring materials to the designated storage area: This process provides 20-25 workers to transport these pieces due to the large volume manually so it took a long time (each piece takes 15-20 minutes) Figure 19.

There was also one crane ready to move these glasses (which was not enough) due to poor coordination to provide the cranes on time (it was the responsibility of the general contractor).Figure 21

3- Storage and Inspection: This process provides 10-15 workers ready to receive pieces with one supervisor to check storage process and specification (as explained previously). In this process there were 2 broken glasses (waste material, time, money) intentional loss. Fig. 7, 8, 9 and unintentional loss (1 glass Carcinogenic). Figure 10, 11, 12. 

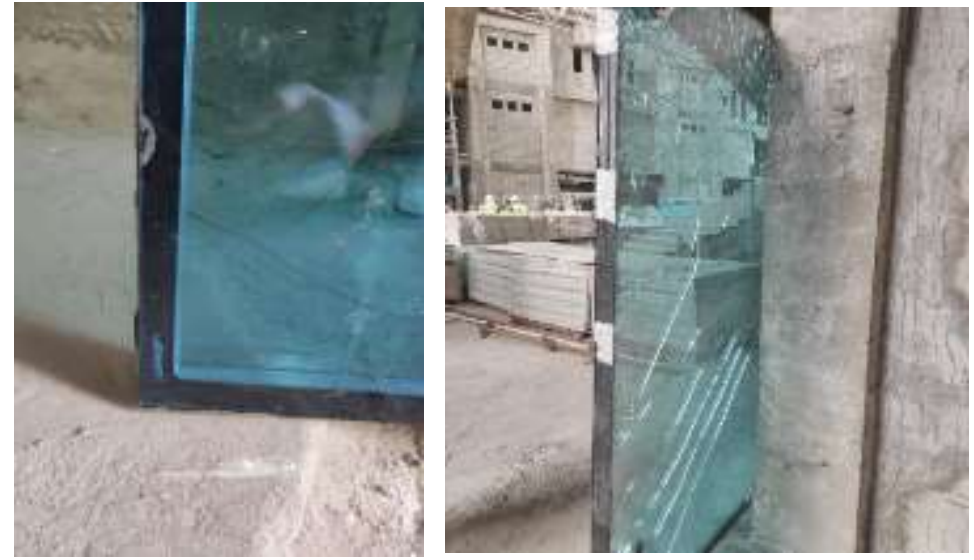

Figure 7,8 : glass broken (deliberate loss)

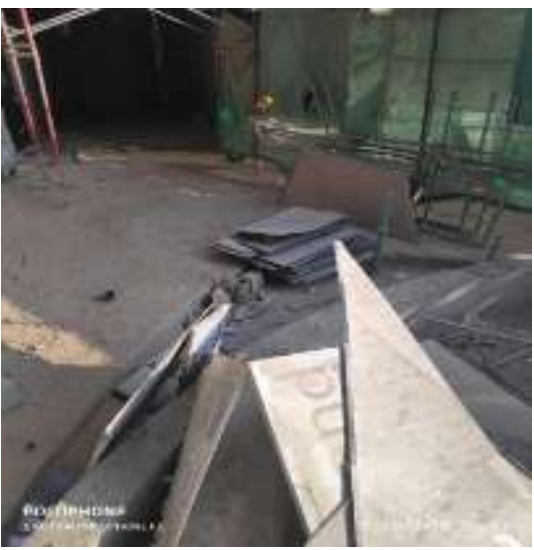

Figure9:Bad storage material

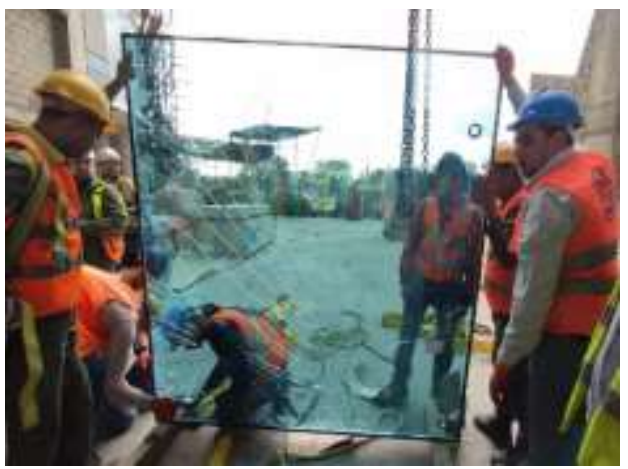

Figure 10 : glass broken (deliberate loss)

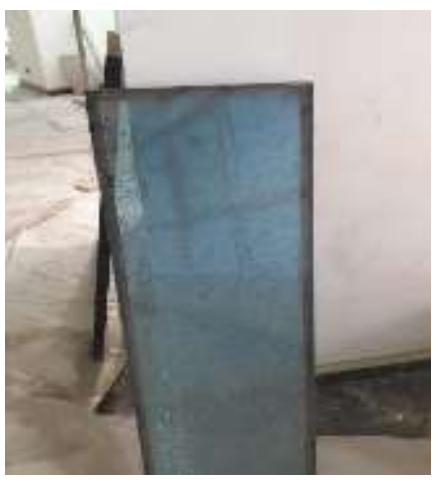

Figure 11,12 : glass Carcinogenic (Undeliberate loss)

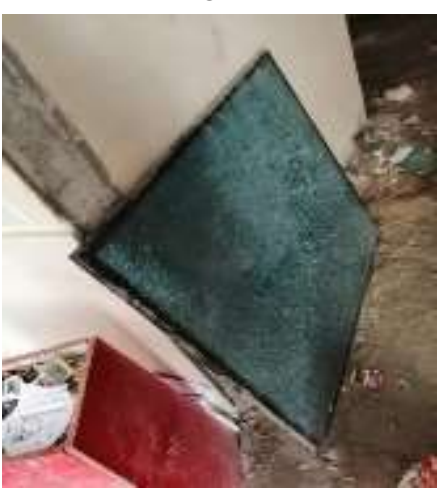

These processes on 4/6/2020 the total period was 12 hours and the project manager was not satisfied with the results of this day, so that he informed the envelope project manager of his comments to try to improve them in the next two shipments.

\section{- Stage 3: Analyze}

Participating parties: Envelope project manager (Alunlie Company), project manager and workers

Activities: Determain the root causes of defects (major defects), which affect the transition to the next step, avoid the waste generation process, avoid defects and assist in moving to the next step (during installing building envelope)

Tools: Cause and Effect Diagram (Fishbone) (17). A cause-and-effect diagram was implemented to analyze the root causes of the waste generated (Fig.13). In order to determine the root and variables causing defects in the activities of this stage, the second step was carried out in several days.

Another day (14/6/2020 the second shipment) was selected from the same avtivities of this step with the same situations and testing the activities of this step to determine the main causes of defects in this step. 
Activities had to be carefully examined and the envelope project manager (Alunlie Company), project manager had to be involved. Different parties were asked to express their opinion on the low quality of activities, including observers and workers.

The Cause and Effect Diagram helped identify the root causes of waste under several categories: material transportation, worker, general contractor, management, materials, equipment, and site works.

Of the potential factors that are considered possible causes of waste, only 17 are included in the cause-and-effect diagram. These 17 were chosen based on the factors that were proposed in the framework of implementing mega envelope upon arrival of the materials in Table $(1,2)$.

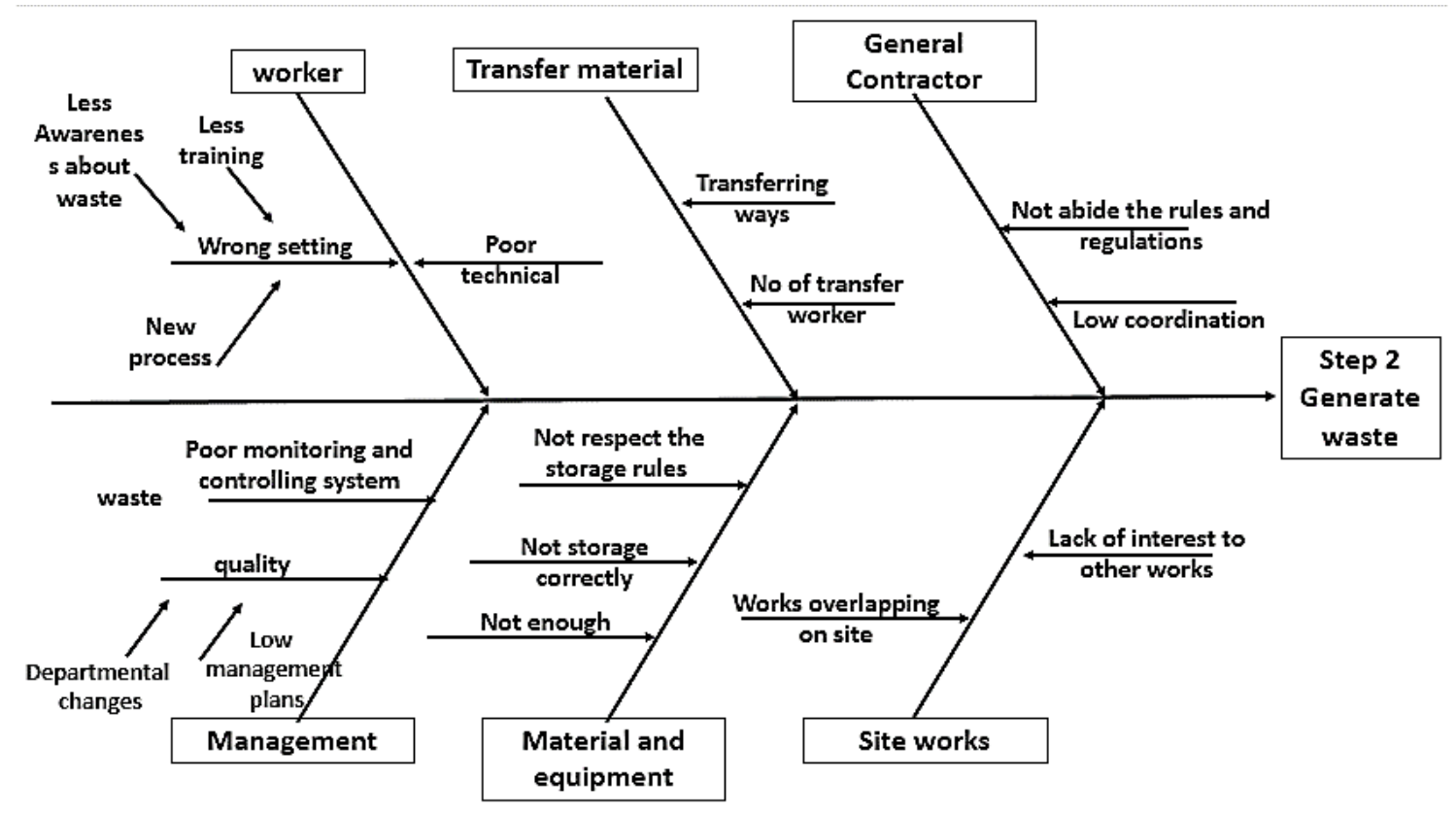

Figure 13 : Cause and Effect Diagram: Common factors causing waste in implementing mega building envelope upon arriving material

\section{- Stage 4: Improve}

Participating parties: Envelope project manager (Alunlie Company), project manager and workers

Activities: - Data given to the improvement process and to give good responses and solutions to each problem

Tools: Modified VSM Tool: Tool The main goal of the modified tool is to eliminate or reduce defects and waste of the activites and increase the efficency, quality.

The list of necessary modified processes that can influence on reduced waste at this stage is:: 
- Supervising the proper droping off of materials from trucks while developing motivational factors for the supervisor and workers.

- Masterly supervision respecting the storage rules indicated by the manufacturer with developing a salary deduction in place instructions were violated

- The use of modern suction equipment to reduce workers in transferring materials.

- Proficient supervision and good management of the presence of hoisting equipment for storage materials during the delivery of materials to avoid damage and waste (time and workers)

- Not to change the company of implementing the envelope several times.

- De-coupling activities and workers in this step from other site works.

Figure 14 illustrates the current modified process. In cooperation with the construction management team, the modified process was successfully applied and the step activities were carefully examined

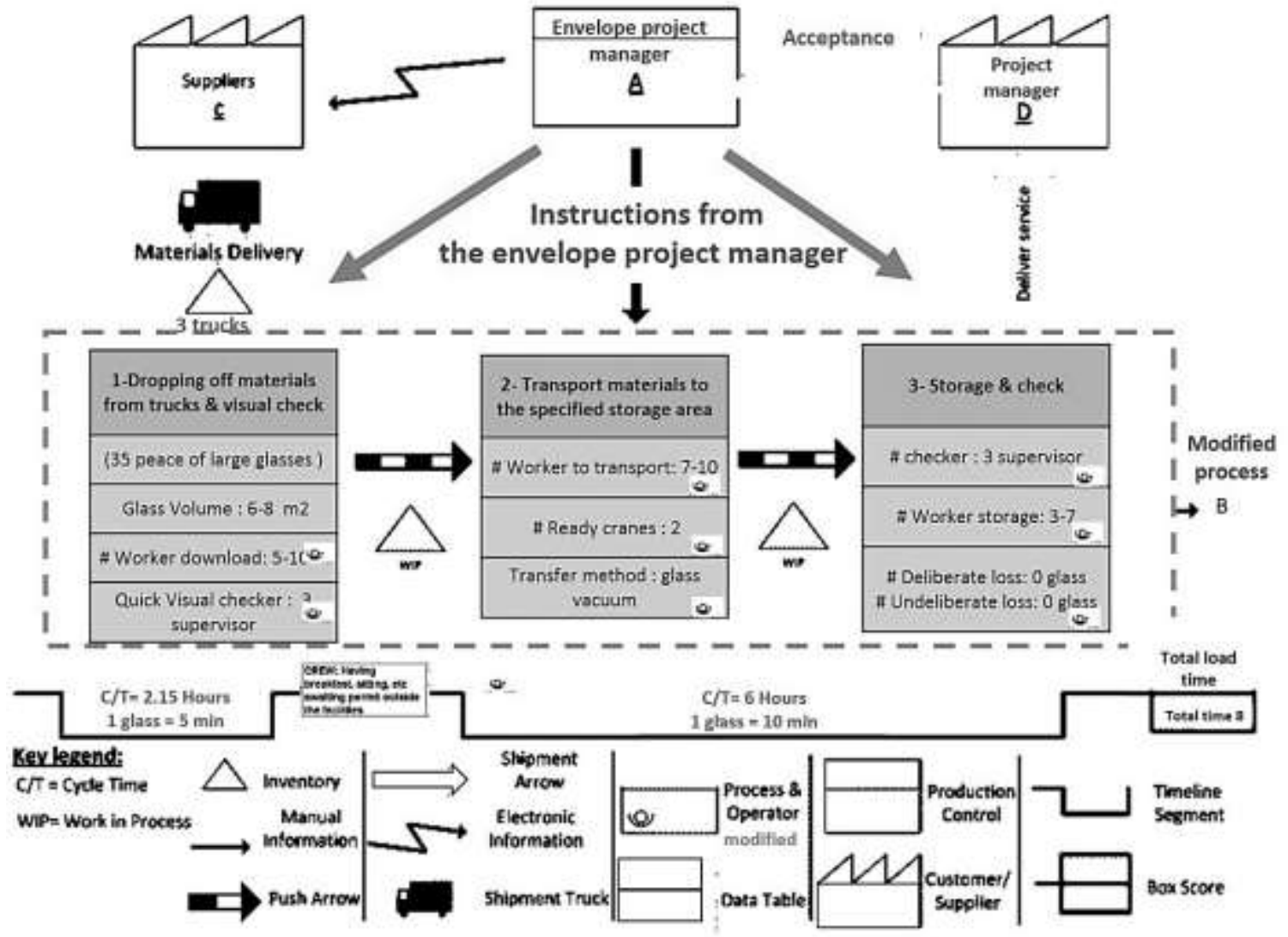

Figure 14. Value Stream Mapping of team Work Preparation Process (Improved)

Source: researcher

From the modified VSM map, the following points were concluded: 
1- Dropping off materials from trucks and visual inspection: This process requires 5-10 workers to unload 35 pieces of large glasses (size $=6-8 \mathrm{~m} \mathrm{2}$ ) (reduce the number of workers) Figure 15.16

During the dropped off of materials, there were 3 quick visual supervisors for this process resulting in further affected work and commitment of workers to the proper download of materials cause them to participate in the improvement process and motivate them financially. Figure 18.

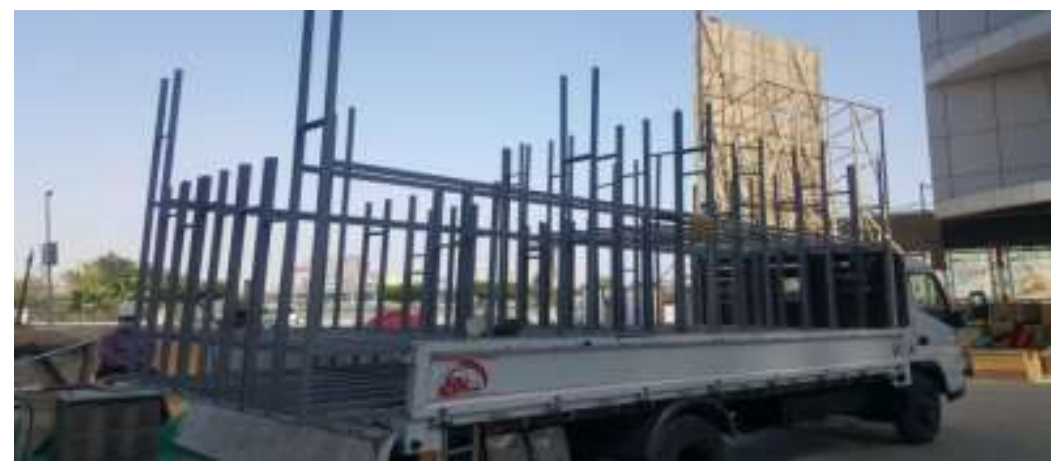

Figure 15 (up) : arriving materials to the site

Figure 16 (right) : Dropping off materials from trucks needs 5-10 (minimize number of worker)

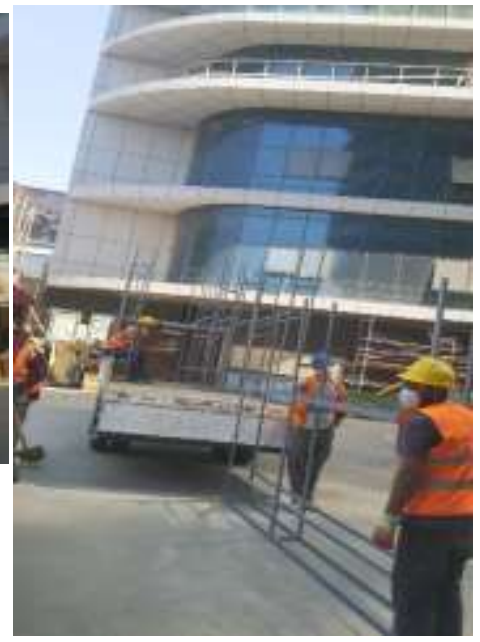

2- Transferring materials to the designated storage area: This process needs 7-10 workers (reduce the number of workers) to transport these pieces using a glass vacuum, so it will take a short time (5-10 minutes). Figure 20

There were 2 cranes ready to move these glasses (more cranes available) Fig. 22, 23 and there was good coordination of the cranes to provide them on time (process improvement).
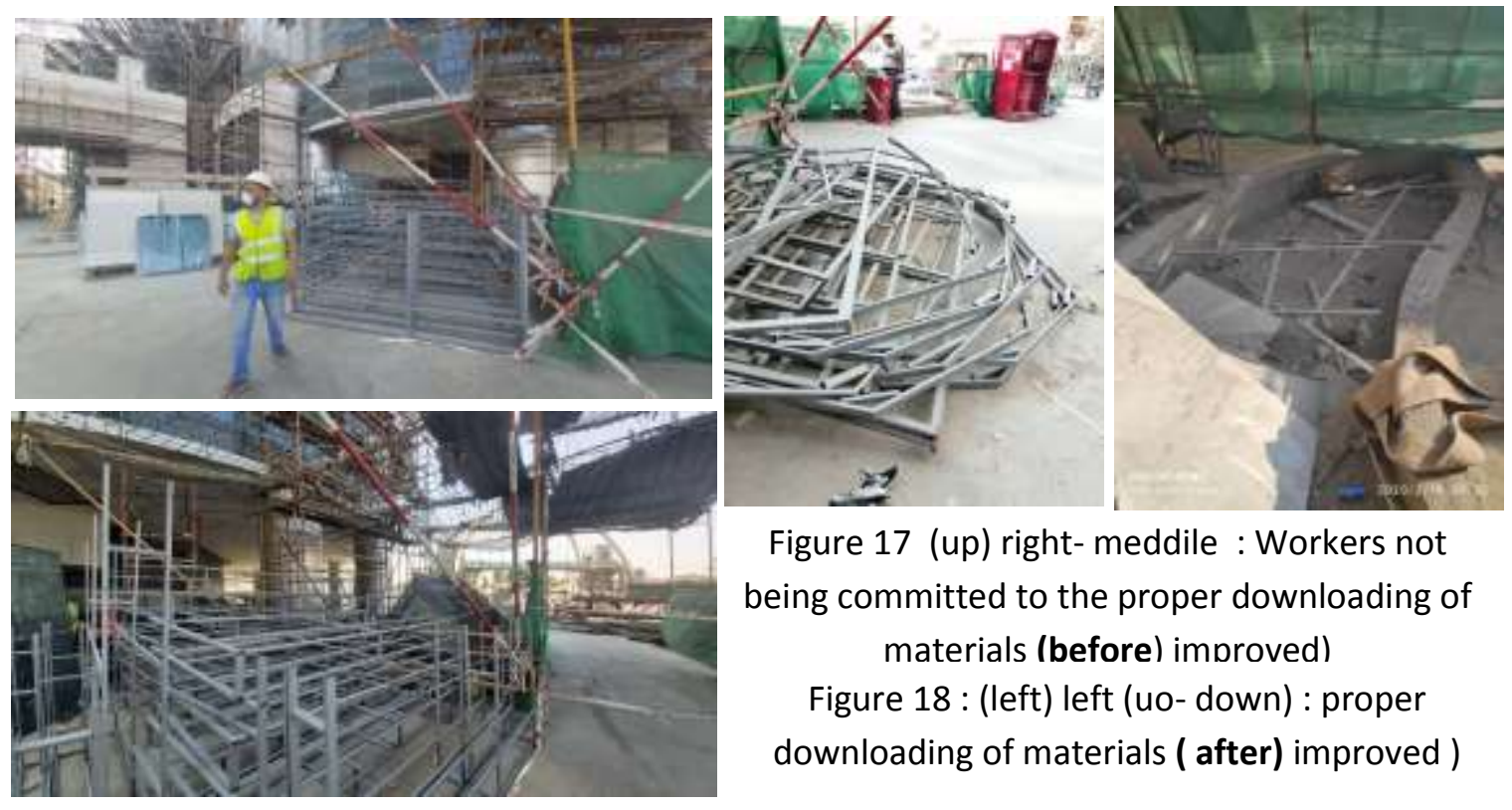

Figure 17 (up) right- meddile : Workers not being committed to the proper downloading of materials (before) improved)

Figure 18 : (left) left (uo- down) : proper downloading of materials ( after) improved) 
3- Storage and Inspection: This process needs 3-7 workers (reducing the number of workers) ready to receive the pieces with 3 supervisors to check the storage process and specifications, as previously explained. In this process, there is no deliberate loss and unintentional loss. Fig 24, 25, 26.

These processes (the second

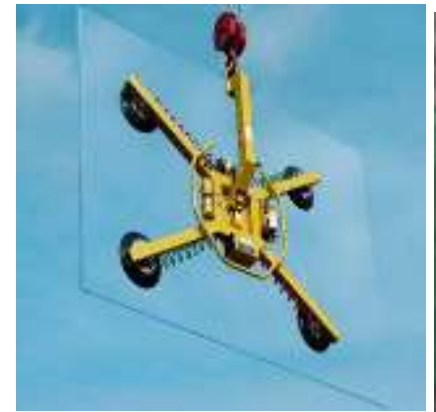

Figure 19 : (right ) Transport to the storage area need 710 worker using glass Figure 20: ( up) Transport materials need 20-25 worker manually (after)

shipment 14/6/2020) their total duration were 8 hours, and the project manager was satisfied with the results of this day and informed the envelope project manager about that. The envelope project manager continued to implement the improved instructions and process.

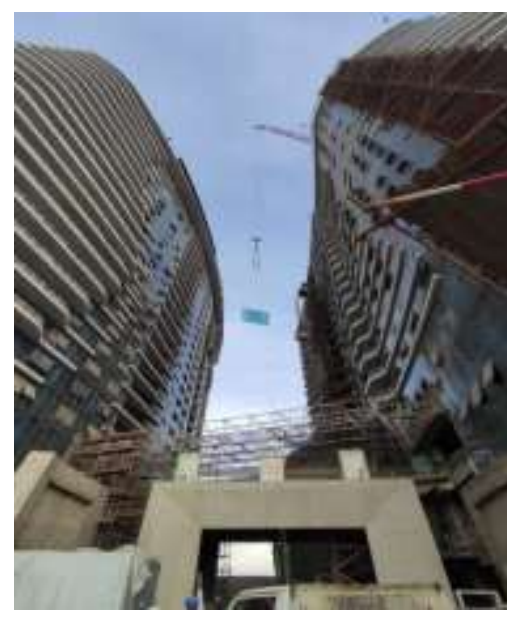

Figure21: 1 crane ready to transport materials (before)

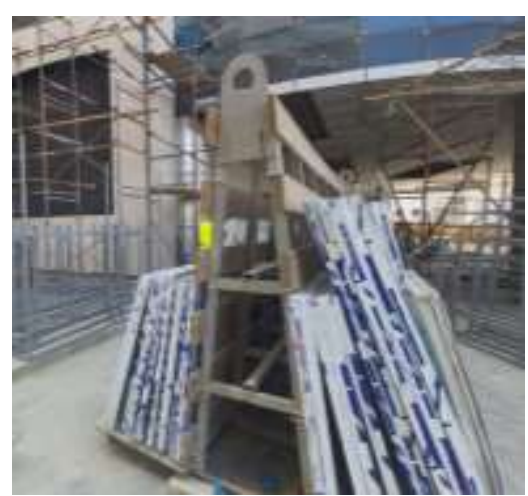

Figure 24,25 , 26 : Material storage (after improved process )
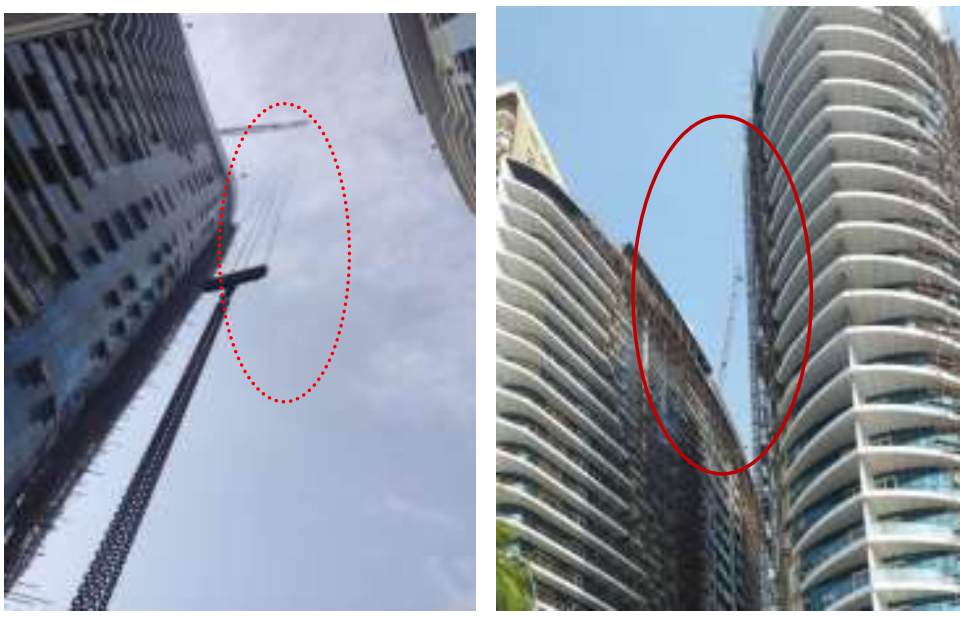

Figure 22,23 : two crane ready to transport materials (after)
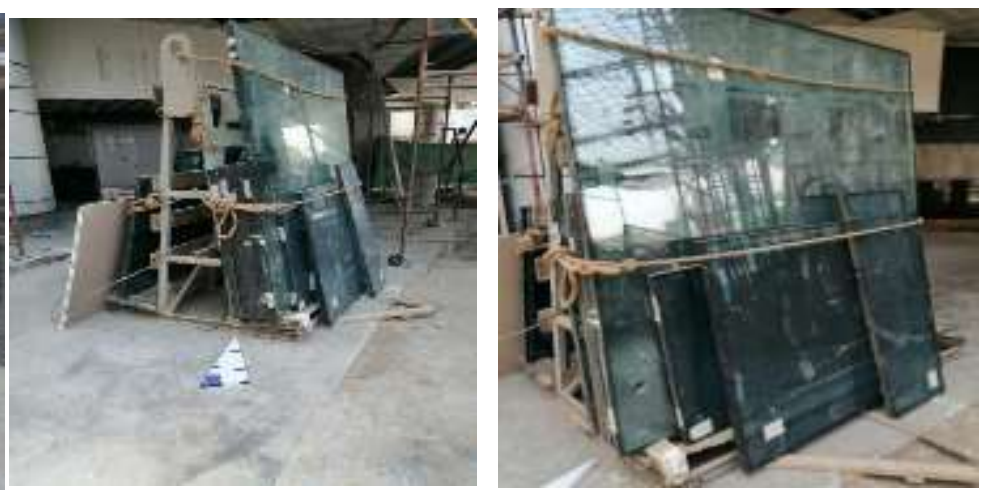

A15 


\section{- Finally Stage 5: Control}

For this step, it carried out a retrospective evaluation of the achieved process performance and the strategies implemented in order to develop improved procedures for better performance in the future. Stage 5 is essential to the methodology: This stage is responsible for maintaining consistent successful performance and continuous improvement.

Actevities: - A dedicated and involved project management team for an unending top to bottom.

- Organizational support should be appointed.

- Setting legitimate plans for quality and waste management.

- Establish performance measures for continuous improvement of processes.

- Forming monitoring and control teams with specialized personalities.

- Quality assessment and benchmarking must be maintained

- Define the new flow system.

Tools: Collecting data - Control charts. The following control charts illustrate the controlled processes that required specialized personnel to conduct quality assessment and benchmarking. These charts contain 3 shipments of supplies to the site for the installation of skylight link for the two towers on these dates (4/6/2020 - 14/6/2020 - 18/6/2020 ) with de-coupling envelope erection from other trades.

\section{Download from lorries \& visual check}

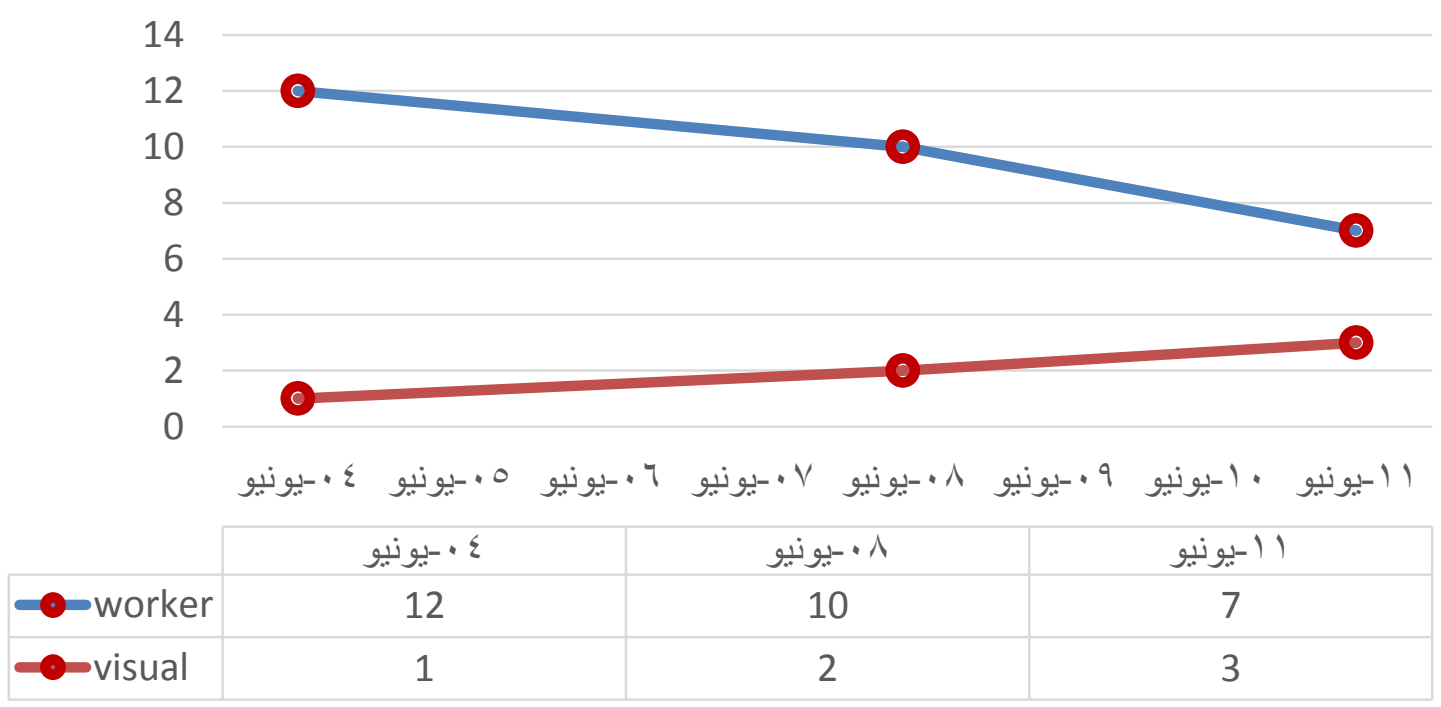

Figure 27: Control Chart of (Process 1) upon building material delivered 
It can be seen from the control chart (Fig. 27) that there is an improvement in the following process:

1- The number of workers decreases in every shipment which reduces wastage (time, worker, money) with high work efficiency.

2- In every shipment there is more visual checker (supervisors) which reduces working time and increases quality.

\section{Transport to the storage area}

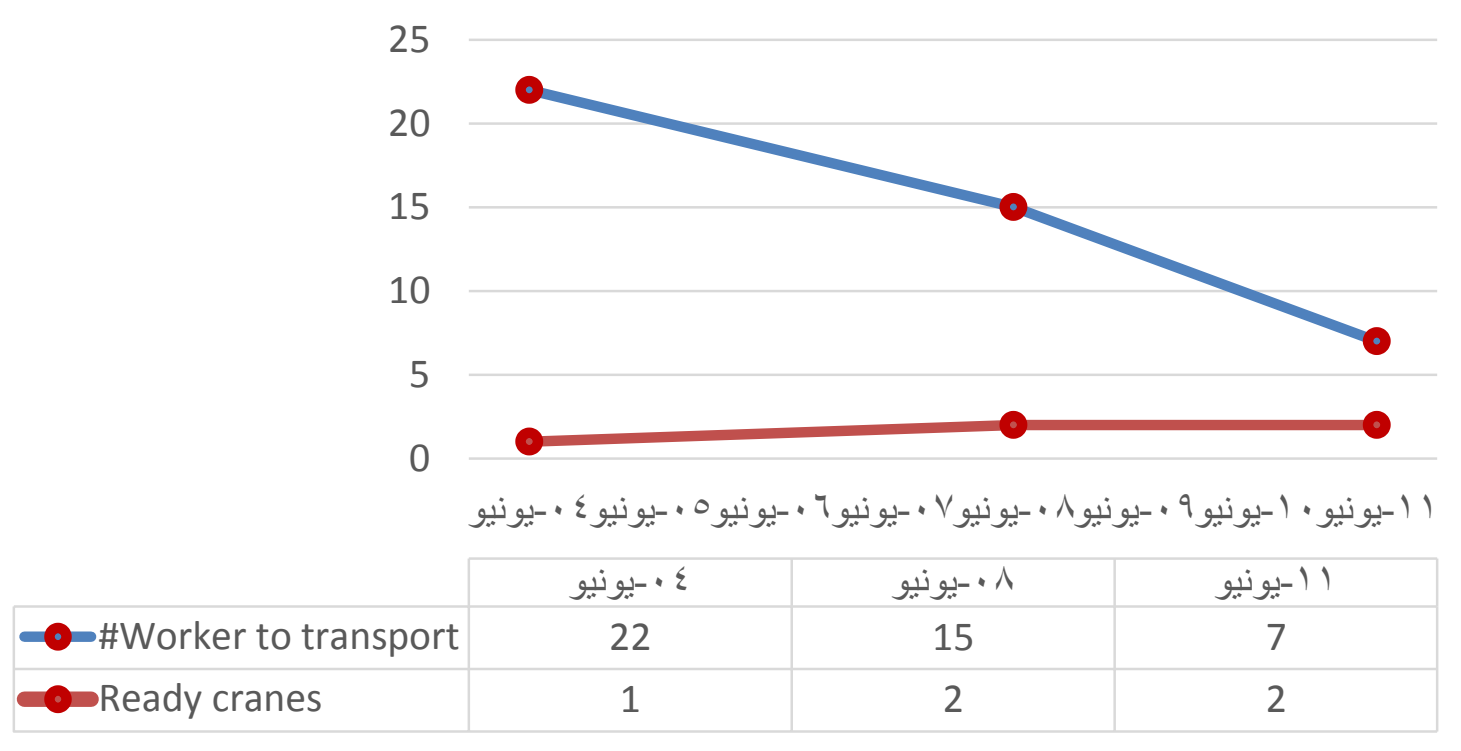

Figure 28 : Control Chart of ( Process 2) upon building material delivered

It can be seen from the control diagram (Fig. 28) that there is an improvement in the following process:

1- The number of workers to transport glass to floors decreases in every shipment which reduces waste (time, worker, money) with high work efficiency (the main reason for this is the use of vacuums to transfer materials instead of the manual method).

2- In every shipment, there were more ready cranes, which reduces work time and increases quality and efficiency, and the reason for this is good coordination.

It can be seen from the control chart (Fig. 29) that there is an improvement in the following process:

1- The number of the material checker is increased after storing the materials, which makes the work faster and of higher quality. 
2- The number of workers who store glasses to floor storage, decreases in every shipment which reduces waste (time, worker, money) with high work efficiency (the main reason for this is the good coordinator and has more supervisors)

3- The number of unintentional losses decreased (because of the increased worker's awareness, has a financial incentive, and a good coordinator and supervisor).

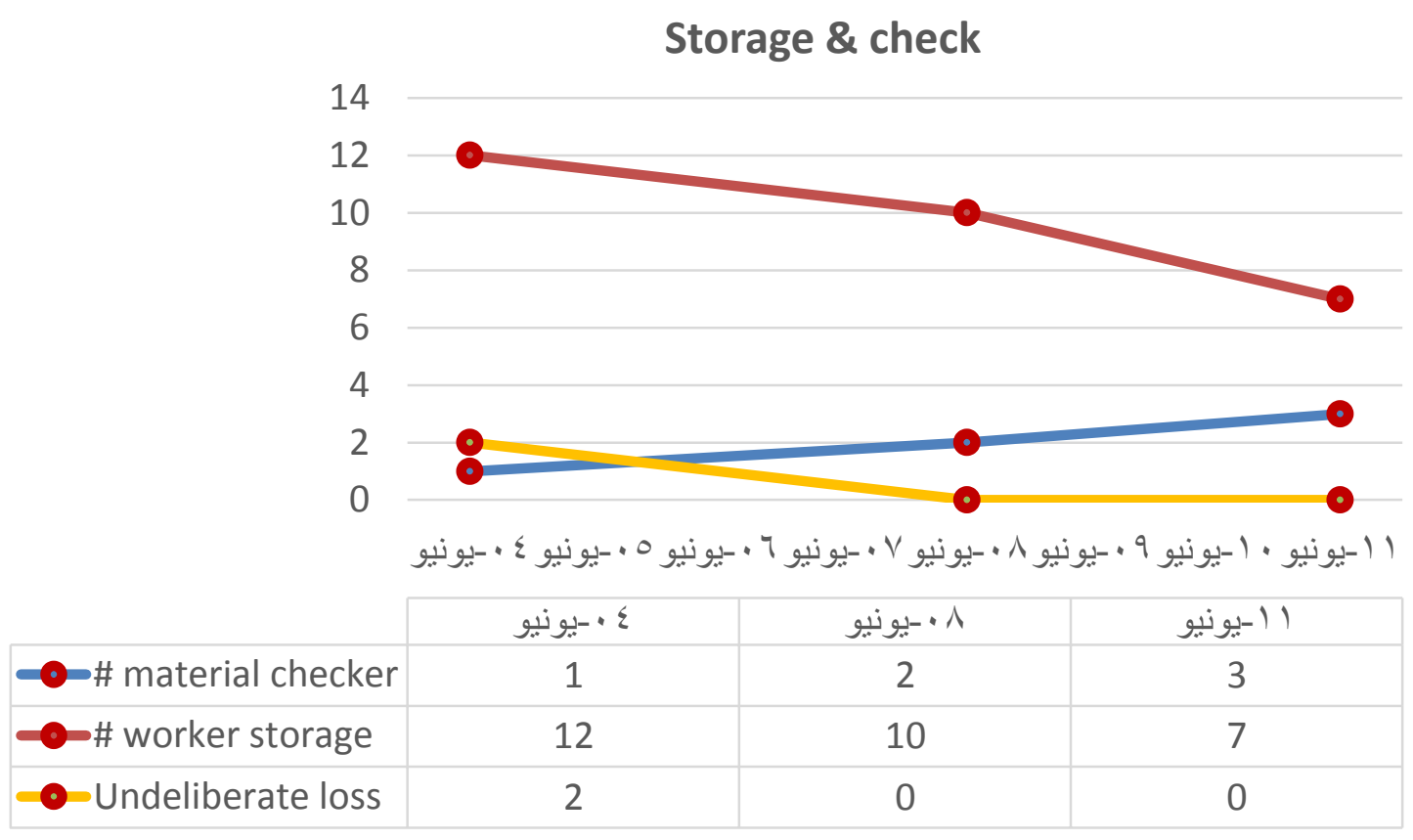

Figure29: Control Chart of ( Process 3) upon building material delivered

From the three control charts, it concluded the following:

1- The time period for each shipment has been reduced (shortening the cycle and reducing waste).

2- The number of transport days for the next shipment has been reduced due to the continuous acceleration and improvement in the operations of each shipment, which will lead to:

- Reduce the project time and follow the schedule as possible.

- Reducing the cost of the process and implementation (material, worker).

- More efficiency and quality in implementing mega building envelope (installation of the highest quality envelope)

- Improving the implementation of mega building envelope during its steps (this is the goal of the paper). 


\section{Conclusions}

The researcher presented a methodology to improve the efficiency of implementing mega structure envelope that can be used by large contracting companies to improve quality, reduce waste in time, materials, and obtain the lowest percentage in the installation of mega building envelope.

To obtain this methodology, the researcher defined the processes and activities of this step and what would be considered. Then marge the frameworks (Mega envelope installation framework upon arriving material, Lean and Six Sigma Framework)

Finally, the researcher presents a case study for applying the methodology of improving the construction process to implement mega structure envelope (upon the arrival of materials to the site) in a case study in Egypt - Cairo - Maadi to further clarify and verify the framework by identifying the root causes responsible for the process and the potential causes of the waste, using Lean and six sigma tools.

A modified process was developed to eliminate the potential causes by applying the process improvement method that resulted in reduced material waste, time duration, and potential savings to reach the goal of this paper and allow for the move to the next implementation processes.

\section{References}

1- https://www.academia.edu/9904984/Long_Span_and_Long_Span_and_co mplex_Structure_complex_Structure

2- https://www.google.com/search"skyscraper".@2012Encyclopædia,Britanni ca, Inc. Retrieved 19 September2012.

3- http://alunile.com/ , http://enclose.com/

4- 2003, Implementing Six Sigma. 2nd Edition,Breyfogle, F. W., Wiley, New York, NY.

5- 2015, Master of Science,POLITECNICO DI MILANO, APPLICATION of 6 SIGMA METHOD in PURCHASING PROCESS, Gokce KURAL\&Alperen OZ.

6- 2017,paper, International Journal of Engineering Technologies and Management Research, AN OVERVIEW OF THE CONCEPT OF LEAN CONSTRUCTION AND THE BARRIERS IN ITS IMPLEMENTATION, Radhika R*1, S.Sukumar 
7- 2006,paper, Lean Construction: From Theory to Implementation, Ossama M. Salem, Journal of Management in Engineering

8- 2008,paper, Sustainable Value on Construction Projects and Lean Construction, Jin-Woo Bae, Yong-Woo Kim, Journal of Green Building

9- https://business901.com/wp- content/uploads/2012/09/Mossman_Last _Planner_5_crucial_conversations-120901_web.pdf.

10-2013, British Library Cataloguing, Implementing Lean in construction: Lean tools and techniques, O'Connor, R, Swain, B

11-2017,paper, AN OVERVIEW OF THE CONCEPT OF LEAN CONSTRUCTION AND THE BARRIERS IN ITS IMPLEMENTATION , Radhika $\mathrm{R} * 1$, S.Sukumar2, International Journal of Engineering Technologies and Management Research

12-2016, diplom,business process improving using lean six sigma: An example of improving the onboarding process, university of ljubljani

13-(Womack and Jones 1996, James-Moore and Gibbons 1997, Hoerl 1998, Rother 1998, Breyfogle III 1999, Harry and Schroeder 1999, Emiliani 2000, Hines and Taylore 2000, Pyzdek 2000, Antony et al. 2003, Snee and Hoerl 2003)

14-2018,Book,Six-Sigma-A-Complete-Step-by-Step,the council for six sigma certificate ,HarmonyLiving,LLC,412N.MainSt,Suit100

15-2014, paper, Implementation of Input-Process-Output Model for Measuring Information System Project Success, A'ang Subiyakto\& Abd Rahman Ahlan, TELKOMNIKA Indonesian Journal of Electrical Engineering

16- 2018,paper, Value Stream Mapping as a Lean Tool for Construction Projects, Murat Gunduz \& Murat Gunduz, Third International Conference on Civil Engineering and Materials Science

17-2018, paper, Diagnosing the Causes of Failure in the Construction Sector Using Root Cause Analysis Technique, Faiq M. S. Al-Zwainy, 1 Ibrahim A. Mohammed,2 and Ibrahim F. Varouqa2, Journal of Engineering 